\title{
Parâmetros acústicos das líquidas do Português Brasileiro no transtorno fonológico***
}

\author{
Acoustical parameters of Brazilian Portuguese liquids in \\ phonological disorder
}

\author{
Luciana de Oliveira Pagan-Neves* \\ Haydée Fiszbein Wertzner**
}

\begin{abstract}
*Fonoaudióloga. Doutora em Semiótica e Linguística Geral pela Faculdade de Filosofia, Letras e Ciências Humanas da Universidade de São Paulo (USP). Fonoaudióloga do Departamento de Fisioterapia, Fonoaudiologia e Terapia Ocupacional da Faculdade de Medicina da (FMUSP). Endereço para correspondência: R. Cipotânea, 51 São Paulo - SP CEP 05360-160 (lucianapagan@usp.br).

** Fonoaudióloga. Professora Associada Livre Docente do Departamento de Fisioterapia, Fonoaudiologia e Terapia Ocupacional da FMUSP.

***Trabalho Realizado no Laboratório de Investigação Fonoaudiológica em Fonologia do Curso de Fonoaudiologia da FMUSP.
\end{abstract}

Artigo Original de Pesquisa

Artigo Submetido a Avaliação por Pares

Conflito de Interesse: não

Recebido em 27.01.2010. Revisado em 16.10.2010; 22.11.2010. Aceito para Publicação em 30.11.2010.

\begin{abstract}
Background: phonological disorder is one of the most frequent speech and language deficit observed in children and therefore studies using objective evaluation measurements should be developed and implemented during the diagnostic process. Aim: to describe the acoustic characteristics of $/ \mathrm{l} /$ and $/ \mathrm{r} /$ liquid sounds. Method: speech production samples of 20 children with and without phonological disorder were gathered and acoustically analyzed. Six words were selected for repetition: /se'bola/, /'lama/, /'mi אu/, /zaka're/, / zi'rafa/, /pa' Kasu/. The analyzed acoustic parameters were F1, F2 and F3, duration and steady-state portion from the target sound and slope analysis. Results: for words containing /l/, the duration parameter was the great differentiator between the two groups; values of the control group were higher than those found for the group with phonological disorder. Considering words containing $/ r /$ that were correctly produced by the control group and that were always substituted by /l/ in the disordered group, parameters involving duration presented higher values in the disordered group. Slope analysis demonstrated higher values for the control group. Conclusion: articulation accuracy of children in the control group was, overall, higher even when considering correctly produced words by the group with phonological disorder containing / $/ \mathrm{l}$. The analysis of other acoustic parameters, as well as the application of these parameters to other sounds of the Portuguese language, can help clinicians to make a precise evaluation and, consequently, to improve their therapeutic work.
\end{abstract}

Key Words: Speech; Speech Acoustics; Phonetics; Speech Production Measurement.

\section{Resumo}

Tema: o transtorno fonológico é uma das alterações de fala e linguagem mais ocorrentes na população infantil e, por isso, pesquisas utilizando medidas de avaliação objetivas devem ser desenvolvidas e aplicadas durante o processo diagnóstico. Objetivo: descrever características acústicas dos sons líquidos /l/ e / $/$. Método: foram coletadas e analisadas acusticamente a produção de 20 crianças com e sem transtorno fonológico. Os seis vocábulos selecionados para repetição foram /se'bola/,/'lama/,/'mi Ku/,/ zaka'rع/, /zi' rafa/, /pa' Kasu/. Os parâmetros acústicos analisados foram F1, F2 e F3, duração e o steadystate (porção estável) do som-alvo e a análise do slope. Resultados: para os vocábulos com /1/, o parâmetro duração foi o grande diferenciador entre os dois grupos sendo os valores do grupo controle maiores que do grupo com transtorno. Para os vocábulos com $/ \varsigma /$ produzidos adequadamente pelos sujeitos do controle e de maneira substituída por /1/ pelo grupo transtorno, os parâmetros envolvendo a pista acústica de duração apresentaram valores do grupo transtorno maiores que do controle. Já nos parâmetros de velocidade de transição da líquida para a vogal subseqüente (medida por meio do slope) os valores foram maiores para o controle. Conclusão: a precisão articulatória do grupo controle é superior, de modo geral, à produção do grupo transtorno mesmo para o som /1/ produzido de forma correta e aceitável para as crianças com transtorno. A análise de outros parâmetros acústicos, bem como a aplicação destes parâmetros para outros sons do Português podem auxiliar de maneira decisiva a avaliação e, consequentemente, o trabalho terapêutico.

Palavras-Chave: Fala; Acústica da Fala; Fonética; Medida da Produção da Fala.

Referenciar este material como:

1 Pagan-Neves LO, Wertzner HF. Acoustical parameters of Brazilian Portuguese liquids in phonological disorder (original title: Parâmetros acústicos das líquidas do Português Brasileiro no transtorno fonológico). Pró-Fono Revista de Atualização Científica. 2010 out-dez;22(4):491-6. 


\section{Introduction}

American and Brazilian studies indicate phonological disorders as the most frequent communicative disorder in preschool children (12).

Liquid sounds are the last to be acquired in both typical and atypical language development. Several studies indicate that liquids from Brazilian Portuguese language are acquired in late development (3-4).

Following technological advances many researchers have used acoustic analysis as a complement to descriptive diagnosis of children with phonological disorder. The presence of phonetic and acoustic distinctions is an evidence that the knowledge children have about the sound system is more sophisticated than one might expect based solely on descriptive phonological analysis.

Acoustic analysis of speech used during evaluation process for the diagnosis of phonological disorders is very important because its results can help in certifying the validity and specificity of data collected even though it is not common for the speech pathologist to use (5-7).

During acoustic analysis of speech many measures can be extracted from the spectrogram. The choice of the most appropriate measurement for each sound must be careful and it varies according to the goals in each analysis.

An innovative measure that has been used to acoustically characterize events in speech is the slope analysis that demonstrates the rate of change from formants in hertz $(\mathrm{Hz})$ within a limited period of time in milliseconds (ms). This measurement has been widely used in studies on dysarthria and it helps to determine the velocity of change in vocal tract configuration when preparing to produce the next sound of a sylllable (8-9).

Aim: To describe some acoustic characteristics from the liquid sounds /l/e /R/ produced by children with and without phonological disorder.

\section{Method}

Subjects

Speech sample from 20 children aged between 5:0 and 12:0 years-old: 10 children without speech disorders (CG) and 10 with phonological disorders (RG). Control group (CG) was composed by five female and five male subjects while research group (RG) was composed by four female and six male.

Criteria for inclusion in CG were the absence of complaints of disorders during phonological development parents and teachers interviews, no more than three episodes of otitis media by collection date and the absence of phonological processes evaluated by the phonology test from ABFW Child Language Test (10).

Inclusion criteria in RG were the diagnosis of phonological disorder presenting only the phonological process of liquid simplification of at least one from the 3 possible liquids from Brazilian Portuguese /l/, /R/ e /'/ (which may be accompanied or not by the process of consonant simplification from both liquids $/ \mathrm{l} /, / \mathrm{R} /$ ) in three or more words in imitation and picture naming tasks. Moreover these children could not have done any type of speech intervention earlier.

Subjects from RG were selected on the Research Laboratory in Phonology at the University where the study was elaborated. CG children were selected from a private school located in the area of the district of Butantan in São Paulo.

Material: Words containing target liquid sounds $/ \mathrm{l} / \mathrm{,} / \mathrm{R} / \mathrm{e} / \mathrm{\prime} /$ were previously recorded by the researcher in a Compact Disc and afterwards presented to both groups. A portable sound system was used to play the words that should be repeated.

Data from the repetitions were collected and stored directly on CSL (Computerized Speech Laboratory manufactured by Kay Elemetrics Model 4300B) using an unidirectional microphone brand Shure model SM-58. Speech samples were analyzed on CSL as well.

Procedure

A protocol to register acoustic analysis from the liquids was elaborated (11). Such protocol contained nine syllables and six words with the three liquids / l /, / r / and / lh /.

Words selected and used in the present research were , /se'bola/, /'lama/, /'mi' u/, /Zaka'RE/ , /Zi'Rafa/, /pa' asu/. Selection from the words was based on phonology task from ABFW Child Language Test (10). All words were repeated three times each.

Criteria for Analysis of Acoustical Parameters:

Spectrographic analysis was performed for each of the 18 repetitions from the 20 subjects of both CG and RG totalizing 360 spectrograms. Each repetition was initially analyzed by waveform visualization and by spectrography afterwards. Acoustic parameters analyzed were formant frequencies F1, F2 and F3, duration from the target 
sound and from the syllable (measured in ms), steady-state from the target sound (measured in ms) which represents the extent of the stable portion and finally, slope analysis was applied in order to evaluate the rate of change from the formants $(\mathrm{Hz})$. Steady-state and slope analysis were measured separately for F1, F2 and F3.Statistical analysis ANOVA test was applied and significance level adopted was 0.05 (5\%).

\section{Results}

Initially it is important to emphasize that every repetition of words containing the liquid sound / $\mathrm{R} /$ by RG were produced as /l/, ie the target words /Zaka'RE/ and /Zi'Rafa/ were produced by these subjects as /Zaka'lE/ e /Zi'lafa/. Repetition of words containing The products containing $/ \mathrm{l} /$ and $/{ }^{\prime} /$ were adequately produced by this group. Subjects from CG produced all the words properly.

Table 1 presents the values of $p$ (ANOVA) when comparing CG $x$ RG considering each target sound according to the acoustic parameters studied.
Words containing the target sound /// presented statistically significant results higher for CG than for RG for the duration from the target sound and for steady state for F2.

Words containing the target sound /R/ presented statistically higher values for GC than for RG only for slope analysis for F1 and F3. All other parameters demonstrated statistically significant values of RG higher than those presented by GC.

Considering words containing the target sound I'/ RG presented higher statistic significant values than CG for duration of the target sound, steady state for F2 and F3 and transition duration for F3.

Table 2 shows the values of $\mathrm{p}$ (ANOVA) for the comparison between $/ \mathrm{R} /$ produced adequately by the subjects from CG and substituted by /// by RG subjects.

At this time statistically significant results higher for RG than for CG were observed for F1 and for the syllable duration and transition duration for F1, F2 and F3. The parameters duration from the target sound, steady state portion as well as slope analysis for F1, F2 and F3 presented higher statistically significant values for CG than for RG.

TABLE 1. Valu es from ANOVA comparison between group s for the target liquids.

\begin{tabular}{|c|c|c|c|}
\hline Parameters & $/ 1 /$ & $/ \Gamma /$ & $/ \kappa /$ \\
\hline F1 & 0,518 & $<0,001^{*}$ & 0,277 \\
\hline F2 & 0,205 & $<0,001^{*}$ & 0,475 \\
\hline F3 & 0,073 & 0,567 & 0,083 \\
\hline Duration from the target sound & $0,033^{*}$ & $<0,001^{*}$ & $0,002^{*}$ \\
\hline Duration from the syllable & 0,524 & $<0,001^{*}$ & 0,380 \\
\hline Steady-state for F1 & 0,059 & $<0,001^{*}$ & 0,051 \\
\hline Steady-state for F2 & $0,036^{*}$ & $<0,001^{*}$ & $0,026^{*}$ \\
\hline Steady-state for F3 & 0,271 & $<0,001^{*}$ & 0,452 \\
\hline Transition duration for F1 & 0,534 & $<0,001^{*}$ & 0,261 \\
\hline Transition duration for F2 & 0,353 & $<0,001^{*}$ & $0,014^{*}$ \\
\hline Transition duration for F3 & 0,085 & $<0,001^{*}$ & 0,385 \\
\hline Slope analysis for F1 & 0,067 & $<0,001^{*}$ & 0,889 \\
\hline Slope analysis for F2 & 0,085 & 0,149 & 0,848 \\
\hline Slope analysis for F3 & 0,266 & $0,030^{*}$ & \\
\hline
\end{tabular}


TABLE 2. Values of the ANOVA in an inter group comparison for the target sound $/ \varsigma /$.

\begin{tabular}{|c|c|}
\hline Parameters & CG X RG \\
\hline F1 & $0,002^{*}$ \\
\hline F2 & 0,241 \\
\hline F3 & 0,853 \\
\hline Duration from the target sound & $<0,001^{*}$ \\
\hline Duration from the syllable & $0,048^{*}$ \\
\hline Steady-state for F1 & $<0,001^{*}$ \\
\hline Steady-state for F2 & $<0,001^{*}$ \\
\hline Steady-state for F3 & $<0,001^{*}$ \\
\hline Transition duration for F1 & $<0,001^{*}$ \\
\hline Transition duration for F2 & $<0,001^{*}$ \\
\hline Transition duration for F3 & $<0,001^{*}$ \\
\hline Slope analysis for F1 & $<0,001^{*}$ \\
\hline Slope analysis for F2 & $0,003^{*}$ \\
\hline Slope analysis for F3 & $0,042^{*}$ \\
\hline
\end{tabular}

\section{Discussion}

In general literature presents few studies on the acoustic analysis of consonants in children, especially on the liquid ones(6).

Duration was the parameter that most differentiated both groups considering the target sound /l/. Despite statistically significant differences indicating that CG produces this sound with a longer duration than the RG the fact that this was the only parameter in which such differences were observed demonstrates that duration is an acoustic cue very important for the production of $/ / /$. Perhaps the fact that RG produced the sound /l/ shorter than CG is an indication of an oral-motor difficulty, even if this difficulty is not perceptually audible.

As children improve their language and oralmotor skills temporal patterns of speech increase approaching to the adult pattern (6). Other studies (12) also emphasize that the strategies of oral-motor control may be modified during the development of speech according to the required task. These data support a possible motor difficulty of children from RG that can be observed through the analysis of the acoustic parameters.

Considering words containing /R/ (produced adequately by CG subjects and substituted by /// by $R G$ ) results indicated that $/ R /$ production is shorter in duration and faster considering the speed of articulatory movements of the /R/ produced as /l/ by RG. This result confirms what was expected that the acoustic characteristics from / $R /$ produced correctly differs from those observed at the same target sound produced in substituted by /1/.

One study (13) with children with speech delay of unknown origin concluded that they can start talking using a slower articulatory rate but usually reach a similar rate to that of their peers with typical development. Even though this study was realized with two groups in similar age results indicated that children from the RG had not been able to achieve the same articulatory rate of their peers from CG and therefore, produced sounds using a longer duration than GC.

Another study using speech rate measurement in Brazilian Portuguese speaking children also indicated that those with phonological disorders presented decreased speech rate when compared to children without speech disorders (14).

This finding reinforces that the longer duration used during liquids production the lower is the articulatory rate at the transition from the target sound to the following one (slope) and on the other hand the shorter the duration, the greater the rate from articulatory change. So we can say that the / $\mathrm{R} /$ produced with shorter duration also requires a faster speed from tongue movement to be perceived as an $/ \mathrm{R} /$. It demonstrates that a slower rate of production implies in an increased sound duration. Although RG used duration as an important parameter to differentiate the liquids produced by them their speech is slower than CG is which can also influence listeners' perception. 
Figure 1a and 1b: Acoustic-visual comparison between a child from CG producing the syllable /la/ extracted from the word /se'bola/ and from the same liquid /l/ produced in substitution to an /R/ in the word /Zi'Rafa/ by a child from RG.

FIGURE 1A. Syllable /la/ produced by a child from CG.

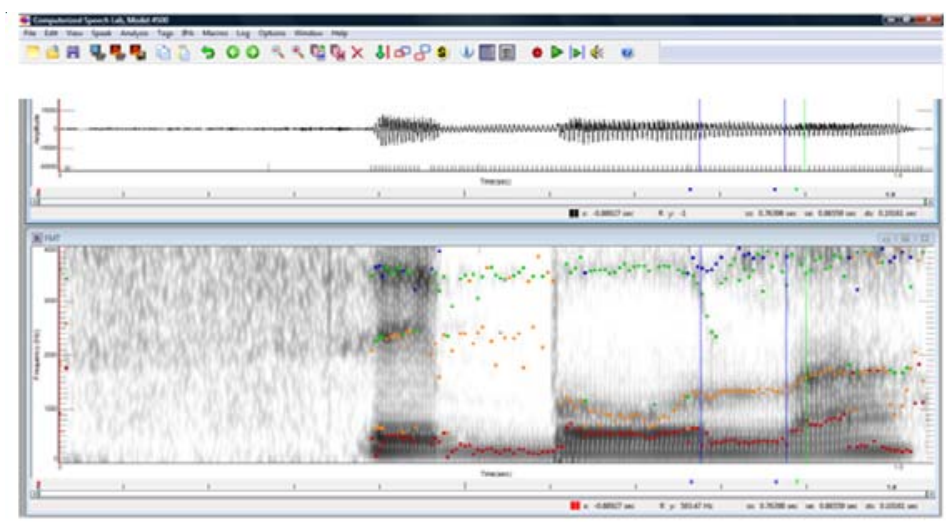

FIGURE 1B. Syllable /R?/ produced as /l?/ by a child from RG.

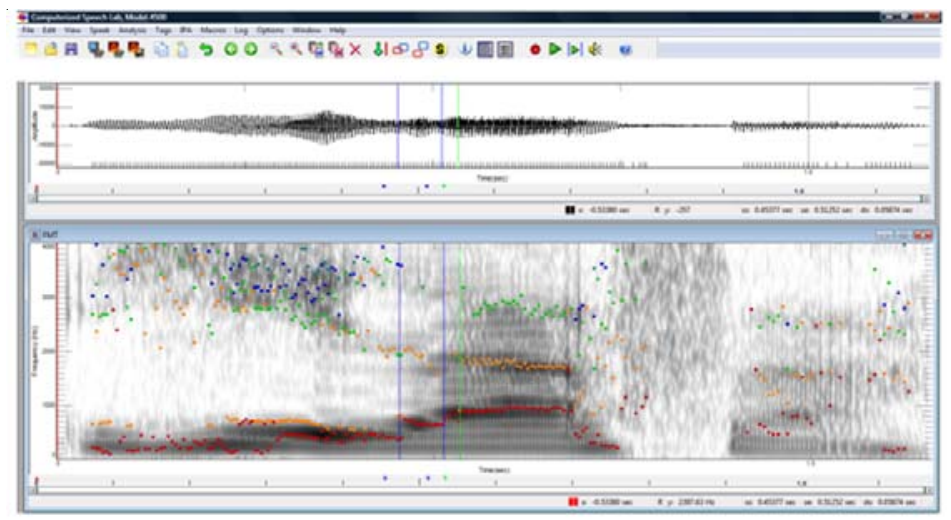

As the liquid /R/ has a short duration the articulatory rate used at the transition from this sound to the next one (measured by slope analysis) is also an important acoustic cue to produce the sound properly. If a particular sound (like the liquid $/ \mathrm{R} /$ ) which is produced with a shorter duration is produced using a slower articulatory rate it might happen that this sound is not identified as the target and may be perceived as distortion by the listener.

Another study (15) reported that tongue tip tends to move faster than the tongue body and that articulatory rate is directly related to the magnitude of articulatory movement. These results also support another Brazilian study (4) which indicated that the production of both distorted or substituted /R/ caused by a difficulty from motor control makes children to develop different strategies to approach the target sound so that they can be understood.

In the analysis of words with /'/ we observed that RG used duration as the most important acoustic cue to differentiate their production from the two other liquids while CG production was based on formant frequencies especially $\mathrm{F} 1$ and F2 to make such differentiation.

Comparison between liquid /l/ produced by CG to the /R/ substituted by /l/ by RG was analyzed to verify whether $R G$ productions presented the same acoustic features as the /l/ produced correctly by CG since all productions from the liquid / $\mathrm{R} /$ by the children with phonological disorders were perceptually identified as an /l/.

Results indicated that duration was the parameter that most differentiated those productions demonstrating that syllables containing the liquid /l/ produced by RG tended to be shorter than those produced by the CG. It indicates that although the liquid /R/ was perceptually identified as an /1/ by the listeners RG children produced a differentiation in their own speech using especially duration as the main important acoustic cue.

In Figure 1 it is possible to observe the difference in both duration and transition from the liquid/l/ produced by a subject from CG and from the liquid /R/ produced as /l/ by a child from RG.

Steady-state statistically significant values for the two groups demonstrated that all subjects produced the three target sounds relying on the stable portion of the liquid. It probably indicates the acoustic differentiation used during the production of these sounds is present after the stable portion of the liquid specifically on the 
transition from the liquid to the following vowel. Again, it is possible to notice that besides duration the velocity applied on the transition from the liquid to the next sound (slope analysis) is very important to the acoustic differentiation for the three liquid Brazilian Portuguese sounds.

\section{References}

1. Gierut JA. Treatment efficacy: functional phonological disorders in children. J Speech Lang Hear Res. 1998;41:S85S100.

2. Andrade CRF, Lopes DMB; Wertzner HF. Uma reflexão sobre a fonoaudiologia preventive. Ciência e Cultura. 1991;43(7):152-3.

3. Teixeira ER, Davis BL. Early Sound Patterns in the Speech of Two Brazilian Portuguese Speakers. Lang and Speech. 2002;45(2):179-204

4. Wertzner HF, Pagan LO, Galea, DES, Papp ACCS. Características fonológicas de crianças com transtorno fonológico com e sem histórico de otite média. Rev Soc Bras Fonoaudiol. 2007;12(1):41-7.

5. Kent RD, Read C. The acoustic analysis of speech. San Diego, California: Singular Publishing Group Inc; 1992.

6. Kent RD, Pagan-Neves LO, Hustad KC, Wertzner HF. Children's speech sound disorders: an acoustic perspective. In: Paul R, Flipsen P. Speech sound disorders in children: in honor of Lawrence D. Shriberg. San Diego, California: Plural Publishing; 2010. p. 93-114.

7. Gurgueira AL. Estudo acústico dos fonemas surdos e sonoros do português do Brasil, em crianças com distúrbio fonológico apresentando o processo fonológico de ensurdecimento [Dissertação de Mestrado]. São Paulo (SP): Universidade de São Paulo, Departamento de Lingüística da Faculdade de Filosofia, Letras e Ciências Humanas; 2000.

\section{Conclusion}

Articulatory accuracy was higher for CG for all the three liquids even for the sound /l/ which was also correctly produced by RG. Thus we can conclude that although we listen to a substitution from /R/ to /l/ acoustic characteristics are different demonstrating that children from the RG tend to produce an acoustic differentiation during the production of the correct /l/ as well as for the /R/ substituted by $/ \mathrm{l} /$.

8. Shadle $\mathrm{CH}$, Mair SJ. Quantifying spectral characteristics of fricatives. Proceedings of the Fourth International Conference on Spoken Language. 1996;3(3-6): 1521-4.

9. Jongman A, Wayland R, Wong S. Acoustic characteristics of English fricatives. J Acoust Soc of Am. 2000;108(3):1252-63.

10. Wertzner HF. Fonologia. In: Andrade CRF de, BefiLopes DM, Fernandes FDM, Wertzner HF. ABFW Teste de linguagem infantil nas áreas de fonologia, vocabulário, fluência e pragmática. Carapicuíba: Ed. Pró-Fono; 2000.

11. Pagan LO. Estudo das líquidas laterais e vibrantes em crianças com distúrbio fonológico: analise acústica e articulatória [Dissertação de Mestrado]. São Paulo (SP): Universidade de São Paulo; 2003.

12. Grigos MI. Changes in articulator movement variability during phonemic development: a longitudinal study. J Speech Lang Hear Res. 2009;52:164-77.

13. Flipsen PJr. Longitudinal changes in articulation rate and phonetic phrase length in children with speech delay. J Speech Lang Hear Res. 2002;45(1):100-10 .

14. Wertzner HF, Silva, LM da . Velocidade de fala em crianças com e sem transtorno fonológico. Pró-Fono Rev Atual Cient. 2009;21:19-24.

15. Butcher A. Measuring coarticulation and variability in tongue contact patterns. Clin Ling Phon. 1989;3(1):3947. 